\title{
The effect of laterite stone as filler on marshall stability hot mix asphalt AC-WC
}

\author{
Istiar ${ }^{l}$, *, Tri Joko Wahyu Adi ${ }^{1}$, Sutikno ${ }^{2}$, Rahmat $^{3}$, Martheana Kencanawati $^{3}$, and Ilham Siara ${ }^{4}$ \\ ${ }^{1}$ Department of Civil Engineering, Institut Teknologi Sepuluh Nopember Surabaya, Jalan Arif Rahman Hakim, Surabaya, Indonesia \\ ${ }^{2}$ Department of Statistics, Institut Teknologi Sepuluh Nopember Surabaya, Jalan Arif Rahman Hakim, Surabaya, Indonesia \\ ${ }^{3}$ Department of Civil Engineering, Universitas Balikpapan, Jalan Pupuk Raya, Balikpapan, Indonesia \\ ${ }^{4}$ Magister Student, Departement of Civil Engineering, Institut Teknologi Sepuluh Nopember Surabaya
}

\begin{abstract}
The highway is the main transportation infrastructure in Indonesia. Most of the highway pavement construction in Indonesia is flexible pavement. The filler commonly used in hot mixture asphalt is Portland Cement. Along with the issue of sustainable development and utilization of local materials, fillers are often replaced with cheaper and easily available materials. One material that can be used as a filler, cheaper and easily available is Laterite.

The experiment was proposed to find out whether laterite could be used as filler material on Asphalt Concrete Wearing Course (AC-WC). The method and technical specification of experiment referred to Asphalt Pavement Specification, that published by Public Work Ministry of Indonesia. The experiment had another objective. The experiment would be examine whether laterite percentage variation on filler material that mixed with Portland Cement, would effect on Marshall Stability value. The filler material was a mixture of laterite and Portland Cement, which the proportion of each were 0:100, 50:50, and 100:0. Each proportion of filler material compacted with 75 and 400 blows. There were 3 samples of each combination of the proportions of the filler material. The total number of specimens were 18. Furthermore, the Marshall stability value of each specimen would be tested using ANOVA test. And ANOVA test used Software Minitab 16.

The experiment result showed, Marshall Stability was greater than 800 kilograms as asphalt concrete wearing course (AC-WC) specification requirement. Analysis of Variance (ANOVA) test results using Minitab 16 software showed no difference in Marshall stability value on all specimens. Because, P-value of Laterite and compaction combination were less than 0.05 .
\end{abstract}

\section{Introduction}

The highway is the main transport infrastructure in Indonesia and the total road length is 523,974 kilometres. Three hundred one thousand and three hundred eighty five of 523,974 kilometres road length had paved. So, there are still more than 40 percent of road length in Indonesia had not paved.

There are two types of road pavement construction in Indonesia. It was flexible pavement and rigid pavement. The mostly used in Indonesia is the flexible pavement. Flexible pavement materials consist of coarse aggregate, fine aggregate, filler and bitumen as binder.

The filler is a fine aggregate that pass sieve number 200 . Filler material is usually used right now, is cement. But, not all regions in Indonesia are available cement material. So, it takes alternative material to replace cement as filler material. Such alternative materials are preferred in many areas where there are road construction projects.
The island of Borneo has large laterite material deposits. The Laterite Stone of Borneo is a hardened soil resembling a stone from the deposition of nickel and iron substances. Laterite stone is formed naturally in which many contain basic solutions. The organic material content is lost due to the weather and leaves the nickel and iron substances that form a layer of soil and harden like a stone.

In Borneo, laterite stones are used as subbase pavement layer because the material is easy to obtain and the quality is also strong. Based on the above background it is necessary to research about laterite stone as filler on asphalt mixture. Whether using laterite stone as filler can influence the value of Marshall test parameters better than using cement filler. It is hoped that with the results of this test the use of laterite stone can be used as an alternative to more expensive cement replacement.

\footnotetext{
${ }^{*}$ Corresponding author: istiar@yahoo.com
} 


\section{Literature Study}

\subsection{Hot Mix Asphalt}

Hot mix asphalt consists of aggregate and bituminous, mixed by heating process on Asphalt Mixing Plant (AMP), spread out and compacted on the base course or subgrade. Several kinds of hot mix asphalt (HMA) are Sand Sheet, (SS), Hot Rolled Sheet, (HRS), and Asphalt Concrete, (AC).

Hot Mix Asphalt material consists of asphalt cement, coarse aggregate, fine aggregate and filler. The gradation of each aggregate size should be check before combined as mix aggregate that fulfilled the job specification of hot mix asphalt.

All hot mix asphalt types are designed by considering percentage of asphalt, air void, stability, flow, void filled with bitumen, and type of traffic.

\subsection{Aggregate}

Aggregate or granular material is grained and compacted materials. The term is including round aggregate, crush aggregate, stone ash and sand. The aggregate is main part in the highway flexible pavement. Because, their percentage is around $90 \%$ until $95 \%$ from total weight hot mix asphalt.

Based on material size, aggregate is consists of 2 kinds, are coarse aggregate and fine aggregate. Coarse aggregate is hard and compacted grained aggregate, including gravel, stone crushed, stone ash and sand. Fine aggregate consists of natural sand, artificial sand or slag sand or a combination of such materials. The fine aggregate must be clean, dry, strong, free of clumps of clay and other disturbing materials and composed of sharply corners and having a rough surface.

\subsection{Filler}

Filler material specification is:

a. For filler material such as stone ash, fly ash, Portland cement or other nonplastic material, filler should be cleaned or free from disturbing material and should be check on wet condition.

b. Filler should be dry and there is no lumps and if tested by sieve, the result must contains materials that pass sieve number 200 (aggregate size 0.075 $\mathrm{mm}$ ) not less than $75 \%$ of total weight. (SNI 03 1968-1990)

\subsection{Asphalt}

Asphalt is defined as dark brown material, at room temperature is solid to slightly solid. If heated to a certain temperature the asphalt becomes soft or liquid so that it can wrap the aggregate particles at the time of making the hot mix asphalt or can penetrate the pores of aggregate when it sprays or mixed on macadam pavement or hot mix asphalt process. If the temperature starts to decrease, the asphalt will be hardening and bond in place (thermoplastic character). As one of the flexible pavement construction materials, the use of asphalt is low, generally only $4 \%-10 \%$ of total weight or $10 \%-15 \%$ of total volume, but asphalt is an expensive material.

Based on how to obtain, type of asphalt is divided by 2:

A. Natural deposits asphalt, consist of

a. Rock asphalt, such as asphalt from Buton

b. Lake asphalt, such as asphalt from Bermudes, Trinidad

B. Processed asphalt, consist of:

a. Asphalt Cement, from natural oil processing

b. Ter, from coal processing. The material is not common used on the highway pavement. Because, the pavement is hardening quickly, and sensitive to temperature changes (Silvia Sukirman, 1995)

\subsection{Bitumen Content Estimation}

Bitumen content on the hot mix asphalt can be estimated by the following formulation:

$$
\begin{gathered}
P B=(0,035 \times \% C A)+(0,045 \times F A)+(0,18 \times F F) \\
+N k
\end{gathered}
$$

Where:

$\mathrm{PB}=$ Bitumen content.

$\mathrm{CA}=$ Coarse Aggregate

FA = Fine Aggregate

$\mathrm{FF}=$ Filler

$\mathrm{Nk}=$ Constant number, $0,5-1$ (for hot mix asphalt ACWC)

\subsection{Laterite Stone}

Based on the USDA classification, Laterite soils have the same name Oxisols. This soil is rich in mineral sochyloid and has more weathering. The soil is poor in rotten minerals, highly resistant mineral content and Cation exchange capacity is very low (Soil Survey Staff, 1998).

This soil is characterized by the presence of horizon oxic at less than $1.5 \mathrm{~m}$ depth or has horizon candic that the amount of mineral easily decayed to meet the requirements of horizon oxic. This soil has special properties such as very low nutrient reserves, very low natural fertility, high interchangeable $\mathrm{Al}$ content, good permeability, and soil against erosion. However, some of these soils (Laterite/Oxisols), for example from the great group Eutrotrorrox, have high base saturation throughout their profiles (Hardjowigeno, 1993).

The process of laterite soil formation is the development of further weathering of Latosol soil. High rainfall (wet or humid) plus high temperatures leads to faster and more intensive soil-development forces in the tropics due to heavy growth. High temperatures accelerate the process of mineralization of organic materials that can offset the process of humification, resulting in $\mathrm{CO}_{2}$ and $\mathrm{H}_{2} \mathrm{O}$. These substances accelerate the process of decomposition of rocks, and also silicate $\mathrm{Al}$ and $\mathrm{Fe}$ by dissolving alkaline ions such as $\mathrm{K}, \mathrm{Ca}, \mathrm{Na}$,

\footnotetext{
${ }^{*}$ Corresponding author: istiar@yahoo.com
} 
and Mg. The absence of a process of gleization enhances the intensity of the base dissolution.

From the description above, the process of Laterite is a further weathering process of Latosol soil where there is a process of removal/ leaching of silica and alkaline ions chemically from soil solum until the concentration of $\mathrm{Fe}$ and $\mathrm{Al}$ is increased relative. Occurs in the tropics where rainfall and high temperatures so that $\mathrm{Si}$ and alkaline ions easily dissolve. Here laterit used in this research.

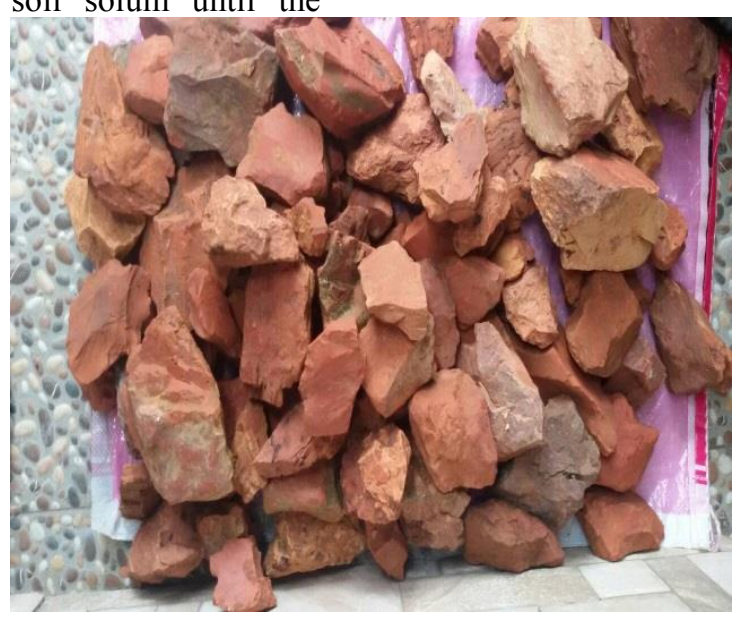

Fig. 1. Laterite Stone

\subsection{Analysis of Variance}

Analysis of variance (ANOVA) is a collection of statistical models and their associated procedures (such as "variation" among and between groups) used to analyze the differences between group means. ANOVA was developed by statistician and evolutionary biologist Ronald Fisher. In the ANOVA setting, the observed variance in a particular variable is partitioned into components attributable to different sources of variation. In its simplest form, ANOVA provides a statistical test of whether or not the means of several groups are equal, and therefore generalizes the $t$-test to more than two groups. ANOVAs are useful for comparing (testing) three or more means (groups or variables) for statistical significance. It is conceptually similar to multiple two-sample t-tests, but is more conservative (results in less type I error) (Diez et all, 2017) and is therefore suited to a wide range of practical problems.

\section{The Method}

The methodology flowchart that guided the experiment was showed as Figure 2.

\section{Result}

\subsection{Material Testing}

The result of aggregate material testing is showed on Table 1:

Table 1. The result of aggregate material testing

\begin{tabular}{|c|c|c|c|c|c|}
\hline Test & $\begin{array}{c}\text { Coarse } \\
\text { Aggregate }\end{array}$ & $\begin{array}{c}\text { Fine } \\
\text { Aggregate }\end{array}$ & Laterite & Reference & Standard Value \\
\hline Fineness Modulus & & $2,44 \%$ & & SNI 03 - 2461 & $2,3 \%-3,2 \%$ \\
\hline Abrasion & $14,86 \%$ & & & SNI 2417:2008 & Max. $40 \%$ \\
\hline Bulk specific Gravity & 2,718 & 2,580 & 2,609 & \multirow{3}{*}{ SNI 1969:2008 } & $>2,5 \mathrm{gr} / \mathrm{cc}$ \\
\hline Effective Specific Gravity & 2,741 & 2,611 & 2,653 & & - \\
\hline Apparent Specific Gravity & 2,783 & 2,663 & 2,728 & & - \\
\hline Absorption & $0,855 \%$ & $1,215 \%$ & $1,678 \%$ & SNI 1970:2008 & $\leq 3 \%$ \\
\hline Atterberg Limit & & & Non Plastic & SNI 03-1966 & - \\
\hline
\end{tabular}

The result of asphalt testing is showed on Table 2:

\footnotetext{
*Corresponding author: istiar@yahoo.com
} 
Table 2. The result of asphalt material testing

\begin{tabular}{|c|c|c|c|c|c|c|}
\hline \multirow{2}{*}{ No } & \multirow{2}{*}{ Testing } & \multirow{2}{*}{ Testing Method } & \multirow{2}{*}{$\begin{array}{c}\text { Test } \\
\text { Result }\end{array}$} & \multicolumn{2}{|c|}{ Specification } & \multirow{2}{*}{ Unit } \\
\hline & & & & Min & Max & \\
\hline 1 & $\begin{array}{l}\text { Penetration at } 25^{\circ} \mathrm{C}, 100 \\
\text { gram, } 5 \text { seconds }\end{array}$ & SNI 06-2456-1991 & 62 & 60 & 70 & $0,1 \mathrm{~mm}$ \\
\hline 2 & Softening point & SNI 06-2434-1991 & 53,5 & 48 & 58 & ${ }^{\circ} \mathrm{C}$ \\
\hline 3 & $\begin{array}{l}\text { Ductility at } 25^{\circ} \mathrm{C}, \\
5 \mathrm{~cm} / \text { minutes }\end{array}$ & SNI 06-2432-1991 & 128 & 100 & - & $\mathrm{cm}^{3}$ \\
\hline 4 & $\begin{array}{l}\text { Solubility Asphalt in } \\
\mathrm{C}_{2} \mathrm{HCL}_{3}\end{array}$ & SNI-06-2438-1991 & 99,5 & 99 & - & $\%$ \\
\hline 5 & Flash Point $\left({ }^{\mathrm{O}} \mathrm{C}\right)$ & SNI 06-2433-1991 & 331 & 200 & - & ${ }^{\circ} \mathrm{C}$ \\
\hline 6 & Specific Gravity & SNI 06-2441-1991 & 1,030 & 1,0 & - & $\mathrm{gr} / \mathrm{cc}$ \\
\hline 7 & Penetration after TFOT & SNI 06-2456-1991 & 52,3 & 54 & - & $\%$ \\
\hline 8 & Ductility after TFOT & SNI 06-2434-1991 & 83,0 & 50 & - & $\mathrm{Cm}$ \\
\hline 9 & Softening point after TFOT & SNI 06-2432-1991 & 53,5 & - & - & ${ }^{\circ} \mathrm{C}$ \\
\hline 10 & Mixing temperature & AASHTO-27-1990 & 150 & - & - & ${ }^{\circ} \mathrm{C}$ \\
\hline 11 & Compaction temperature & AASHTO-27-1990 & 145 & - & - & ${ }^{\circ} \mathrm{C}$ \\
\hline 12 & Paraffin content & SK-SNI M-09-1993-03 & 0,440 & - & - & $\%$ \\
\hline 13 & Ductility & ASTM D 113 & 150 & Min 100 & - & $\mathrm{Cm}$ \\
\hline 14 & Fresh Point COC & ASTM D 92 & 347 & Min 200 & - & ${ }^{\circ} \mathrm{C}$ \\
\hline 15 & $\begin{array}{l}\text { Loss on Heating } 5 \mathrm{Hrs} \text { at } \\
163^{\circ} \mathrm{C}\end{array}$ & ASTM D 5 & 0,01 & - & Max 0,04 & $\%$ \\
\hline 16 & Penetration at $25^{\circ} \mathrm{C}$ & ASTM D 5 & 62 & $60-79$ & $60-79$ & $0,1 \mathrm{~mm}$ \\
\hline 17 & $\begin{array}{l}\text { Penetration after loss on } \\
\text { heating }\end{array}$ & ASTM D 5 & 93 & Min 75 & - & $\%$ \\
\hline 18 & Softening point ring $\&$ ball & ASTM D 36 & 48,2 & 48 & 58 & ${ }^{\circ} \mathrm{C}$ \\
\hline 19 & Specific Gravity $25 / 25^{\circ} \mathrm{C}$ & ASTM D 70 & 1,0443 & Min 1,0000 & - & - \\
\hline
\end{tabular}

\footnotetext{
*Corresponding author: istiar@yahoo.com
} 


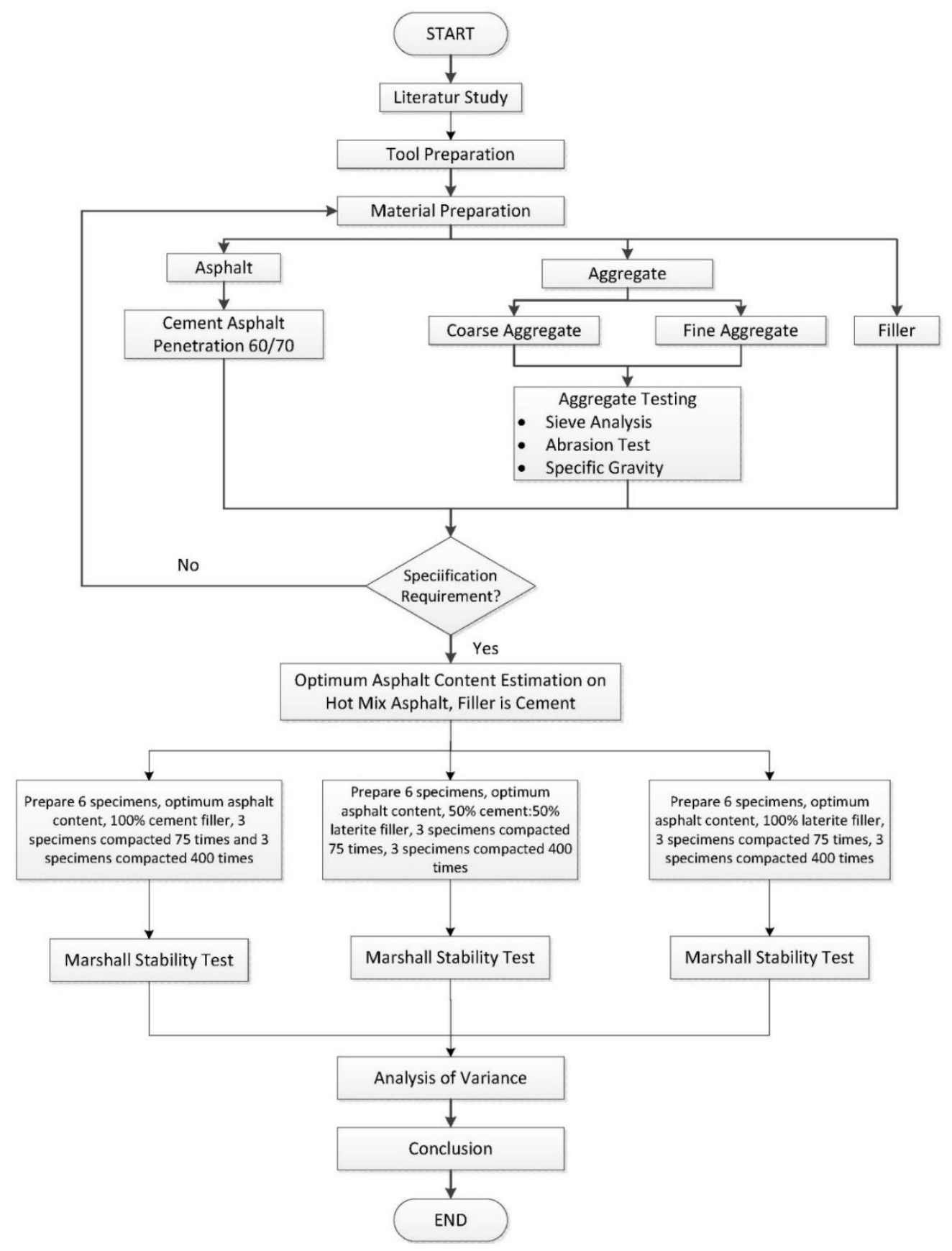

Fig. 2. Methodology Flow Chart

\subsection{Optimum Asphalt Content}

First experiment was done to decide the optimum asphalt content. The optimum asphalt content was obtained by Marshall Stability testing on hot mix asphalt specimen. Hot mix asphalt specimen was made with variation percentage of asphalt content level to total weight specimen. There were six specimens with different variations of asphalt content, i.e. $4.0 \%, 4.5 \%$, $5.0 \%, 5.5 \%, 6.0 \%, 6.5 \%$. Each specimen was tested by
Marshall Test Equipment. The test results were shown by correlation chart between asphalt content with stability, flow, void in mixture (VIM), void filled with bitumen (VFB), and void in mineral aggregate (VMA). Correlation charts between asphalt content with stability, flow, void in mixture (VIM), void filled with bitumen (VFB), and void in mineral aggregate (VMA) can show on Figure 3. 

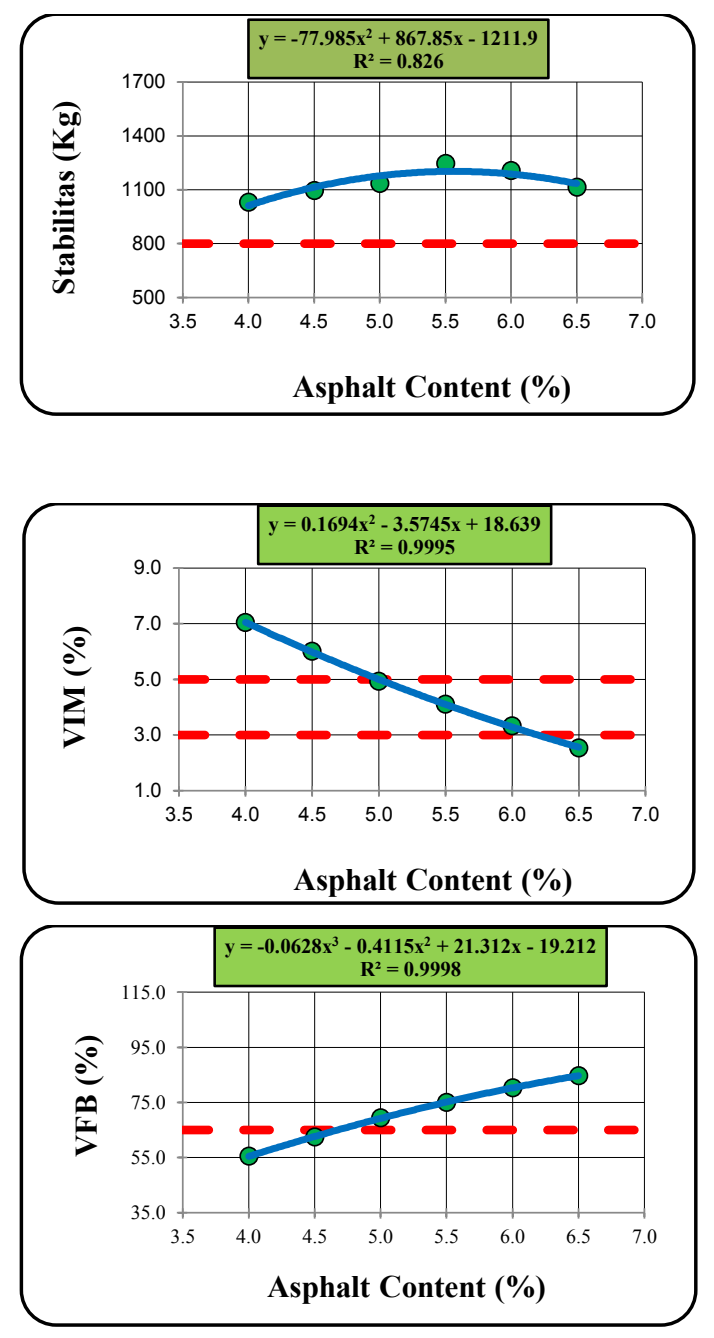

Fig. 3. Correlation Charts between Asphalt Content with Stability, Flow, Void in Mixture (VIM), Void Filled with Bitumen (VFB), and Void in Mineral Aggregate (VMA)

On Figure 3, dashed line showed specification limit, that had to be fulfilled for standard of Asphalt Concrete Wearing Course (AC-WC) mixture. So, recapitulation value from correlation charts between asphalt content with stability, flow, void in mixture (VIM), void filled with bitumen (VFB), and void in mineral aggregate (VMA) that fullfiled for standard of
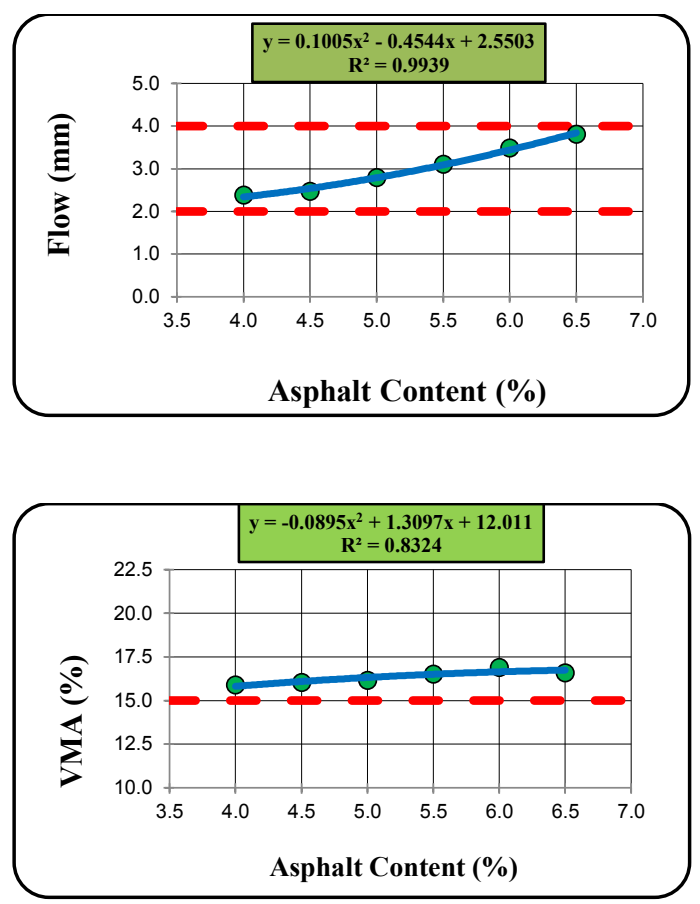

Note:

Trendline testing point chart Testing point chart Specification limit

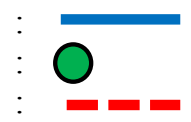

Asphalt Concrete Wearing Course (AC-WC) mixture is showed on Figure 4.

\footnotetext{
*Corresponding author: istiar@yahoo.com
} 


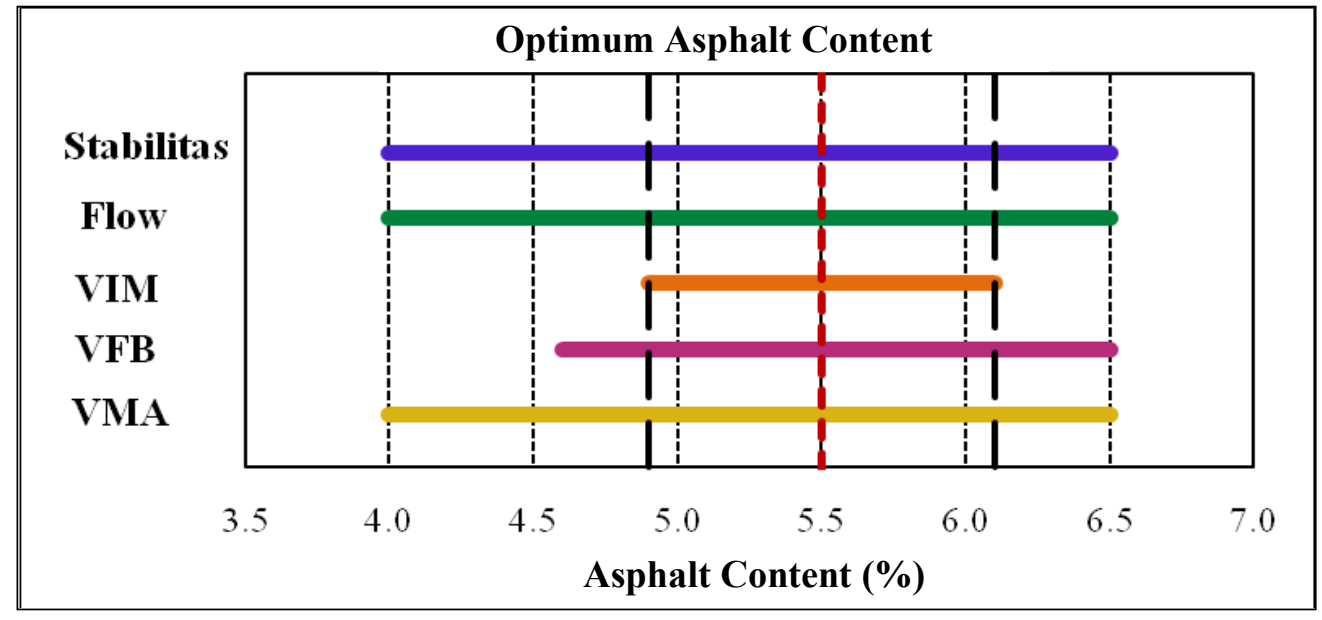

Fig. 4. The Chart of Optimum Asphalt Content Procedure

Note:

Optimum Asphalt Content value

Stability value

Flow value

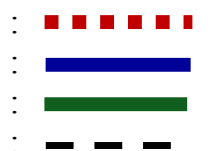

VIM value

VFB value

Optimum Asphalt Content limit

VMA value

On Figure 4, optimum asphalt content value is 5.5\% to total weight hot mix asphalt specimen.

\subsection{Analysis of Variance (ANOVA)}

Analysis of Variance (ANOVA) was used to analysis the effect of laterite on Marshall Stability value. The experimental applied 2 factors, laterite content on filler and number of compaction on hot mixture asphalt.
Laterite content on filler was made 3 level, $0 \%$ leterite: $100 \%$ cement, $50 \%$ leterite: $50 \%$ cement, and $100 \%$ leterite: $0 \%$ cement. Number of compaction on hot mixture asphalt was made 2 level, $2 \times 75$ times and $2 \times 400$ times. Total experiment factors combination were 6 . Number of specimen was 3 of each experiment factors combination. Total specimen were 18. Marshall stability values on 2 factors combination of experiment is showed on Table 3.

Table 3. the Effect of Laterite as Filler on Marshall Stability Specimen

\begin{tabular}{|c|c|c|c|c|c|c|}
\hline \multirow[b]{2}{*}{ No. } & \multirow[b]{2}{*}{ Laterite Level } & \multicolumn{2}{|c|}{ Compacted $2 \times 75$ times } & \multicolumn{2}{|c|}{ Compacted 2 x 400 times } & \multirow{2}{*}{$\begin{array}{c}\text { Specification } \\
\text { (kg) }\end{array}$} \\
\hline & & $\begin{array}{c}\text { Stability } \\
\text { (kg) }\end{array}$ & $\begin{array}{c}\text { Stability } \\
\text { Average (kg) }\end{array}$ & $\begin{array}{c}\text { Stability } \\
\text { (kg) }\end{array}$ & $\begin{array}{c}\text { Stability } \\
\text { Average (kg) }\end{array}$ & \\
\hline \multirow[t]{3}{*}{1} & \multirow{3}{*}{$\begin{array}{l}\text { Cement Filler } \\
100 \%\end{array}$} & 1.248 & \multirow{3}{*}{1.231} & 1.098 & \multirow{3}{*}{1.140} & \multirow{3}{*}{ Min 800} \\
\hline & & 1.223 & & 1.198 & & \\
\hline & & 1.223 & & 1.123 & & \\
\hline \multirow[t]{3}{*}{2} & \multirow{3}{*}{$\begin{array}{l}\text { Cement Filler } \\
50 \% \text { and } \\
\text { Laterite Filler } \\
50 \%\end{array}$} & 1.071 & \multirow{3}{*}{1.107} & 1.000 & \multirow{3}{*}{1.041} & \multirow{3}{*}{ Min 800} \\
\hline & & 1.155 & & 1.024 & & \\
\hline & & 1.095 & & 1.098 & & \\
\hline \multirow[t]{2}{*}{3} & \multirow{2}{*}{$\begin{array}{l}\text { Laterite Filler } \\
100 \%\end{array}$} & 1.024 & \multirow{2}{*}{1.056} & 1.024 & \multirow{2}{*}{1.012} & \multirow{2}{*}{ Min 800} \\
\hline & & 1.048 & & 976 & & \\
\hline
\end{tabular}

\footnotetext{
*Corresponding author: istiar@yahoo.com
} 
On table above, Laterite can be used as filler on asphalt concrete wearing course (AC-WC). Because, Marshall Stability value was greater than 800 kilograms as specification requirement.

There was a hypothesis that should be tested. The tested hypothesis $\left(\mathrm{h}_{0}\right)$ was, no difference of any Marshall Stability value on 18 hot mix asphalt specimen. The hypothesis was tested by using Minitab Sofware. The output minitab as result of tested hypothesis is shown below:

\section{General Factorial Regression: Response versus Laterite; Compaction}

Factor Information

$\begin{array}{lll}\text { Factor } & \text { Levels } & \text { Values } \\ \text { Laterite } & 3 & 0 ; 50 ; 100 \\ \text { Compaction } & 2 & 75 ; 400\end{array}$

Analysis of Variance

$\begin{array}{llllll}\text { Source } & \text { DF } & \text { Adj SS } & \text { Adj MS } & \text { F-Value } & \text { P-Value } \\ \text { Model } & 5 & 96209 & 19241.8 & 11.89 & 0.000 \\ \text { Linear } & 3 & 94479 & 31493.1 & 19.46 & 0.000 \\ \quad \text { Laterite } & 2 & 74144 & 37072.2 & 22.91 & 0.000 \\ \quad \text { Compaction } & 1 & 20335 & 20334.7 & 12.56 & 0.004 \\ \text { 2-Way Interactions } & 2 & 1730 & 864.9 & 0.53 & 0.599 \\ \quad \text { Laterite*Compaction } & 2 & 1730 & 864.9 & 0.53 & 0.599 \\ \text { Error } & 12 & 19421 & 1618.4 & & \\ \text { Total } & 17 & 115630 & & & \end{array}$

In Minitab output, The result was no difference of any Marshall Stability value based on Laterite and compaction combination. P-value was less than 0.05 .

\section{Conclusion}

Conclusion of the experiment were:

a. Optimum asphalt content that used on asphalt concrete wearing course (AC-WC) was 5.5\%.

b. On table above, Laterite can be used as filler on asphalt concrete wearing course (AC-WC). Because, Marshall Stability value was greater than 800 kilograms as specification requirement.

c. Marshall Stability value did not depend on percentage Laterite content and compaction energy.

\section{References}

1. Chapter VII, $6^{\text {th }}$ Division, Asphalt Pavement Specification. Public Work Ministry, Jakarta, (2010).

2. Diez, David M; Barr, Christopher D; Cetinkaya Rundel, Mine. Open Intro Statistics (3rd ed.). Open Intro. Retrieved 11 November 2017, (2017)

3. Sukirman, Silvia, Highway Pavement. Bandung, Nova, (2003)

4. Suryadharma, Hendra; Susanto, Benidiktus (2008), Highway Engineering, Yogjakarta, Universitas Atma Jaya Yogjakarta, (2008).

\footnotetext{
*Corresponding author: istiar@yahoo.com
} 